\title{
Economic Analysis of Products Liability: Theory*
}

\author{
by
}

Andrew F. Daughety and Jennifer F. Reinganum

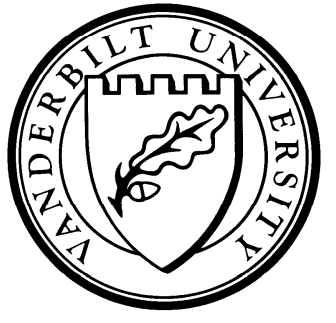

Working Paper No. 11-W07

First Version: November 2010

Revised: May 2011

\section{DEPARTMENT OF ECONOMICS \\ VANDERBILT UNIVERSITY \\ NASHVILLE, TN 37235}

www.vanderbilt.edu/econ 


\title{
Economic Analysis of Products Liability: Theory*
}

\author{
Andrew F. Daughety \\ Jennifer F. Reinganum \\ Department of Economics \\ and Law School \\ Vanderbilt University \\ andrew.f.daughety@vanderbilt.edu \\ jennifer.f.reinganum@vanderbilt.edu
}

First version: November 2010

This version: May 2011

* Forthcoming in Research Handbook on the Economics of Torts, Edited by Jennifer H. Arlen (to be published by Edward Elgar). We gratefully acknowledge research support under National Science Foundation grant SES08-14312, as well as very helpful comments on an earlier draft from Jennifer Arlen, Mitch Polinsky, Kathy Spier, Abe Wickelgren, and an anonymous reader. 


\section{Introduction}

This chapter provides a survey of much of the recent theoretical analysis of products liability. In Section 2, we describe an idealized model and provide the specific economic assumptions which underpin it. Later sections examine the effects of relaxing these assumptions, which has been the focus of much of the theoretical work over the last few decades. These modifications include: informational differences between producers and consumers that arise over the life of a product (Section 3); incorporation of endogenously-determined costs, such as those that arise from investment in care (Section 4); and evaluating contractual versus mandatory liability (Section 5). We briefly summarize the implications of these departures from the idealized model in the conclusion (Section 6). Due to space limitations we will not examine consumer choice of care, consumer risk aversion, consumer behavioral departures from rationality, externalities to nonconsumers, ${ }^{1}$ liability insurance for firms, and judgment-proofness (via bankruptcy) of firms.

\section{A Comparison of Liability Regimes In an Idealized Model}

In this section, we describe an idealized model of a market in which the consumption of the relevant product may cause harm. ${ }^{2}$ The firm(s) supplying the product may engage in care (or precaution) in order to reduce the expected harm associated with the product, and a higher choice of care is assumed to raise the marginal cost of production. We will try to be very explicit about the underlying assumptions, since we will subsequently relax some, but not all, of these assumptions. Throughout we will maintain the assumptions that: 1) consumers and firms are risk-neutral;2) the

\footnotetext{
${ }^{1}$ Hay and Spier (2005) show that, when the consumer may be insolvent, then (abstracting from litigation costs) efficient care is taken when the residual harm to third parties (that is, the excess of realized harm over the consumer's available wealth) is shifted to the firm. Polinsky and Shavell (2010) argue, relying on a model such as that of Section 2, that only the harms of third parties should be shifted to the firm since a consumer will shift her expected harm to the firm through the market price. However, as noted by Goldberg and Zipursky (2010), it may be very difficult to distinguish between consumers and third parties. For instance, the smoker at home exposes family members; should those non-smoking family members be viewed as third parties?

2 Early formal models include Spence (1977), Polinsky (1980), Shavell (1980), and Landes and Posner (1981, 1985).
} 
probability and level of harm are proportional to the quantity consumed; and 3) the cost of production is proportional to the quantity produced. These are clearly restrictive since consumers are especially likely to be risk averse, the probability and level of harm might well depend nonlinearly on the cumulative consumption of the product, and the firm's cost of production might well vary non-linearly with its quantity of output. Nevertheless, we will maintain these assumptions throughout in order to focus on relaxing some of the (standard) assumptions discussed below. We focus on three liability regimes:

- no liability, which is often associated with products wherein assumption of risk places all liability for harm on the consumer (for example, see Jones v. Dressel, 623 P.2d 370 (Colo. 1981), wherein the plaintiff crashed an airplane after signing a waiver of liability as part of a contract with the defendant);

- strict liability, which is employed to address manufacturing defects, generally viewed as non-systematic in nature (for example, see Shoshone Coca Cola Bottling Co. v. Dolinski, 82 Nev. 439 (1966), wherein a mouse was found by a consumer in a bottle of a beverage); - negligence, which is the primary scheme for considering both design defects, generally viewed as systematic problems with all units of a specific product (for example, see Grimshaw v. Ford Motor Co., 174 Cal. Rptr. 348 (1981), wherein the location of the gas tank in all models of the Pinto was susceptible to exploding in a moderate, rear-end collision) and "marketing" or warning defects (for example, see Burch v. Amsterdam, 366 A.2d 1079 (DC Ct of App, 1976), concerning insufficient warning on the label of a hazardous product).

While the legal literature tends to view negligence and strict liability as very different regimes, Craswell and Calfee (1986) provide a formal model of negligence with an uncertain due care standard and show how this transforms the model of negligence to resemble strict liability. Thus, while officially no liability, strict liability, and negligence are distinct regimes, our discussion 
below emphasizes strict liability (and no liability), with comments on negligence as appropriate.

\subsection{Assumptions that Characterize the Idealized Model}

The idealized model considered in this section relies on the following assumptions.

A1. Care is observable to the consumer prior to purchase, and verifiable by a court postpurchase.

A2. Prior to purchase, the firm and the consumer are either fully-informed, or equallyuninformed, about the probability and magnitude of the harm.

A3. The firm does not receive any private information after the consumer has purchased the product but before harm has occurred.

A4. The cost of care is proportional to the quantity produced by the firm.

\subsection{Notation and Formal Model}

A simple formal model can be used to analyze and illustrate the various liability scenarios. The notation to be used throughout the paper is described below; additional notation is developed as needed in subsequent sections.

q denotes a consumer's level of consumption of the product.

$\mathrm{N}$ denotes the number of consumers.

$\mathrm{x}$ denotes a firm's level of precaution or care.

$h(x)$ denotes the expected harm per unit consumed; $h^{R}$ is the realized value of harm.

$\mathrm{k}(\mathrm{x})$ denotes the expected litigation costs per litigant per unit consumed; $\mathrm{k}^{\mathrm{R}}$ is the realized value of litigation costs.

$\mathrm{u}(\mathrm{x})$ denotes the expected uncompensated loss to the consumer per unit consumed.

$\mathrm{v}(\mathrm{x})$ denotes the expected liability cost borne by the firm per unit sold.

$\mathrm{c}(\mathrm{x})$ denotes the production cost per unit when the level of care is $\mathrm{x}$.

$\mathrm{p}(\mathrm{q} ; \mathrm{x})$ denotes the consumer's willingness-to-pay for another unit when she consumes $\mathrm{q}$ units and the firm's level of care is $\mathrm{x}$.

$\Pi(\mathrm{Nq} ; \mathrm{x})$ denotes the firm's profit from selling q units to each of $\mathrm{N}$ consumers when its level 
of care is $\mathrm{x}$.

Care, $\mathrm{x}$, can be viewed as a level of effort, which in turn influences the likelihood and magnitude of harm as well as the unit cost of production. We refer to $\mathrm{h}(\mathrm{x})$ as the expected harm in order to incorporate the possibility that the occurrence of harm, as well as its magnitude, is random, but its distribution is affected by the level of care (as $\mathrm{x}$ increases, $\mathrm{h}(\mathrm{x})$ decreases); $\mathrm{h}^{\mathrm{R}}$ refers to the actual level of harm that occurs (is realized). Similarly, as x increases, the expected litigation costs, $\mathrm{k}(\mathrm{x})$, decrease (for simplicity of exposition, we assume that the realized and expected litigation costs are the same for both litigants); $\mathrm{k}^{\mathrm{R}}$ refers to the actual level of litigation costs, should litigation occur. The consumer's expected uncompensated harm $\mathrm{u}(\mathrm{x})$ reflects the possibility that the consumer may not be fully compensated for the harm and might also bear litigation costs when the firm is liable. The firm's expected liability cost $\mathrm{v}(\mathrm{x})$ includes expected compensatory transfers to the consumer as well as litigation costs when the firm is liable. As $\mathrm{x}$ increases, both $\mathrm{u}(\mathrm{x})$ and $\mathrm{v}(\mathrm{x})$ decrease. The production cost per unit $\mathrm{c}(\mathrm{x})$ increases as $\mathrm{x}$ increases.

The consumer's willingness-to-pay for a unit of the product depends upon the expected uncompensated losses that she expects to bear as a consequence of consumption. Assumptions A1 and A2 ensure that the consumer can correctly anticipate expected uncompensated losses, since the firm does not have any private information as compared to the consumer. In particular, a riskneutral consumer simply subtracts the expected uncompensated losses from her basic willingness-topay for the product. A simple inverse demand curve ${ }^{3}$ that illustrates the model is $p(q ; x)=\alpha-\beta q-$ $\mathrm{u}(\mathrm{x})$, where both $\alpha$ and $\beta$ are positive constants: the consumer's willingness-to-pay is decreasing

\footnotetext{
${ }^{3}$ Although we have couched the model in terms of a single individual consuming multiple units, we could alternatively construct a market demand curve with essentially the same form by aggregating many heterogeneous consumers' willingnesses-to-pay for a single unit.
} 
in the quantity consumed (reflecting diminishing marginal utility for the product), and in the expected uncompensated loss. In some of the subsequent sections, when the main point can be made in an even simpler model, we will assume that the consumer wants at most one unit of the good.

The firm's total cost if it sells q units to each of $\mathrm{N}$ consumers can be written as $[\mathrm{v}(\mathrm{x})+$ $\mathrm{c}(\mathrm{x})] \mathrm{Nq}$; that is, the firm faces a cost per unit that is comprised of expected liability costs plus production costs. An increase in care increases the firm's unit cost of production, but it reduces the expected liability costs (when the firm is liable).

In order to compare perfectly- and imperfectly-competitive markets, we will typically consider the extremes of perfect competition and monopoly, and simply indicate whether the result is robust to intermediate market structures. Sometimes consideration of intermediate market structures provides particular insights, in which case we will describe the operation of such markets in greater detail; this is particularly the case in Section 4.

If the firm is a monopolist, then firm profit (assuming it sells q units to each of $\mathrm{N}$ consumers) is given by (where we have substituted $\alpha-\beta q-\mathrm{u}(\mathrm{x})$ for the inverse demand function $\mathrm{p}(\mathrm{q} ; \mathrm{x})$ ):

$$
\Pi(N q ; x)=[\alpha-\beta q-u(x)] N q-[v(x)+c(x)] N q .
$$

Alternatively, if the firm is a price-taker (i.e., the market is perfectly competitive), then the consumer will be willing to pay $\mathrm{P}-\mathrm{u}(\mathrm{x})$ per unit, where $\mathrm{P}$ is the competitive equilibrium price for a product causing no harm. Then firm profit (assuming it sells q units to each of $\mathrm{N}$ consumers) is given by:

$$
\Pi(N q ; x)=[P-u(x)] N q-[v(x)+c(x)] N q .
$$

Notice that in both equations (1) and (2), we can collect the terms involving $\mathrm{x}$ to obtain the following coefficient for $\mathrm{Nq}$ : $[\mathrm{u}(\mathrm{x})+\mathrm{v}(\mathrm{x})+\mathrm{c}(\mathrm{x})]$. This includes the unit expected harm (plus expected litigation costs if the firm is liable) and the unit production cost. We will refer to this as 
the "full marginal cost" (or FMC) of a unit of the product; regardless of how the harm is allocated initially between the consumer and firm, the firm ends up facing the full marginal cost. Notice also that choosing the level of care to maximize profit is equivalent to choosing care to minimize the FMC, regardless of whether the firm is a monopolist or a price-taking firm. Thus, although a monopolist and a price-taking firm will produce different levels of output, ${ }^{4}$ they will both choose care $\mathrm{x}$ to minimize $\mathrm{FMC}(\mathrm{x})$ : in the idealized model, market structure (the degree of competitiveness of the industry) has no effect on the level of care that the individual firm(s) take. The first two terms in the expression for the full marginal cost decrease as care increases, while the last term increases as care increases. Thus, we assume that $\mathrm{FMC}(\mathrm{x})$ is a "U-shaped" function of care. Hence, there is a unique value of care that minimizes the full marginal cost; we denote this value by $\overline{\mathrm{x}}$.

\subsection{A Comparison of Liability Regimes}

Most of the elements of the model above are independent of the liability regime; however, the sum $\mathrm{u}(\mathrm{x})+\mathrm{v}(\mathrm{x})$ does vary with the liability regime. As a consequence, the level of care that minimizes the full marginal cost will also vary with the liability regime. Under no liability (signified by the superscript NL), $\mathrm{u}(\mathrm{x})=\mathrm{h}(\mathrm{x})$ and $\mathrm{v}(\mathrm{x})=0$; thus $\mathrm{FMC}^{\mathrm{NL}}(\mathrm{x})=\mathrm{h}(\mathrm{x})+\mathrm{c}(\mathrm{x})$. The firm takes care, even when there is no liability, because $\mathrm{x}$ affects the consumer's willingness-to-pay. Let $\overline{\mathrm{x}}^{\mathrm{NL}}$ denote the firm's optimal care level under no liability. Under strict liability (signified by the superscript SL), $u(x)+v(x)=h(x)+2 k(x)$; thus FMC ${ }^{S L}(x)=h(x)+2 k(x)+c(x)$. Let $\bar{x}^{S L}$ denote the firm's optimal care level under strict liability. The foregoing means that the optimal level of care is higher under strict liability than under no liability; that is, $\overline{\mathrm{x}}^{\mathrm{SL}}>\overline{\mathrm{x}}^{\mathrm{NL}}$. Intuitively, there is an additional

\footnotetext{
${ }^{4}$ If the industry producing this good were imperfectly competitive (e.g., an oligopoly), then again a different output level would occur, but each firm would still choose the level of care that minimizes FMC(x).
} 
marginal benefit to care under strict liability because avoiding accidents reduces litigation costs.

Since there are no externalities in the idealized model, the FMC that the firm faces is the same as the full marginal social cost (conditional on a given liability regime); thus, the firm chooses the same level of care as would a social planner. However, litigation costs are introduced along with strict liability, and are not otherwise productive. Moreover, since the FMC of a unit of output is higher under strict liability than under no liability (by the magnitude of expected litigation $\operatorname{costs}{ }^{5}$ ), less output will be produced for any given market structure under strict liability. Consequently, in the idealized model, no liability is socially-preferred to strict liability.

The model under the negligence liability regime (with an associated due care standard) is a hybrid of the no-liability and strict-liability models. If the consumer observes that the firm has met the due care standard, then she knows that she will bear the cost of harm and deducts this from her willingness-to-pay. If the consumer observes that the firm has not met the due care standard, then she knows she will receive some compensation and deducts only her expected uncompensated harm and her expected litigation costs (while the firm adds the expected liability payment and its expected litigation costs to its cost function). The firm then chooses its optimal output level and whether to meet the due care standard. If the due care standard is set equal to the optimal no-liability care level, then the firm will meet the standard and the accident costs will simply reflect the expected harm; that is, no litigation costs will be generated. Thus, care and market behavior will be the same under negligence as under no liability. Note that this result relies on the fact that consumers can predict that any suits they might file would fail (and thus they won't file them). If there is some possibility that harmed consumers would file suits even though the firm has met the due care

\footnotetext{
5 The magnitude of expected litigation costs is a matter of debate. If a case goes to trial, then litigation costs may be quite high. If the outcome is predictable so that the case is likely to settle, then litigation costs may be moderate or low.
} 
standard, then negligence will involve some litigation costs and therefore it will perform worse than no liability. Thus, in the idealized model, no liability is (at least weakly) socially-preferred to negligence.

Finally, most economic models of tort law consider the effects of liability regimes on two outcomes: the level of care taken by, and the activity level of, the injurer. In the idealized model all transactions are via the product market, so the activity level is the level of output (q). Absent litigation costs all liability regimes will produce the same activity level (though now market structure will matter, since a monopoly restricts output).

In what follows, we will relax the assumptions enumerated at the beginning of this section, one at a time, to assess what role they play in obtaining the results that: (1) the firm chooses the care level that minimizes full marginal cost; (2) the firm's optimal level of care is independent of the market structure in which firms operate; (3) the firm's optimal care level coincides with the socially- efficient care level (contingent on the liability regime in place); and (4) the regime in which firms bear no liability for harm is socially-preferred to other liability regimes. We will focus on strict liability rather than negligence, since strict liability is used most often in formal models in the literature. As mentioned above, if the due care standard is taken to be uncertain then, on an $e x$ ante basis (that is, before any harm occurs), negligence will be (formally) very similar to strict liability, especially since our version of strict liability allows for plaintiffs to be under-compensated (which will also occur with positive probability under negligence if the due care standard is uncertain).

\section{Informational Differences}

In this section we consider the effects of informational differences between a firm producing 
a product with important safety characteristics and consumers who may buy such products. We restrict attention to products with potential harms that are not sufficiently great as to warrant their absolute removal from the market (e.g., "easy-strike" matches for toddlers), though recalls of products that might severely harm consumers will be included in one of the later subsections.

What do we mean when we refer to informational differences in a model of products liability? Technically, such models involve what is known as asymmetric information, wherein one party to an exchange knows relevant information that is unknown by the other party. ${ }^{6}$ In this section we focus on one-sided asymmetric information settings, wherein the firm knows some aspect of the true safety level of its product (the firm is the "informed agent"), but the consumer does not know this information (the consumer is the "uninformed agent"). Thus, an informed firm is one that possesses private information about its product while the uninformed, but rational, consumer does not possess the same information but is assumed to know the possible values the information could take on and the likelihood that any of those values would occur. This could arise either because the firm chooses a level of care that is not observable to the consumer, or because the firm has learned about the safety of its product, but the consumer is not privy to this information. ${ }^{7}$

Moreover, two other characteristics about an informational difference matter: 1) when does the informed party learn the relevant information - is it before or after exchange takes place? and

\footnotetext{
${ }^{6}$ Note that this could be true about both parties to an exchange: each may have relevant information. For example, a defendant in a dispute might know his culpability in regards to a harm, but the plaintiff might know the actual degree of harm she has suffered.

7 There is a previous literature on consumer "misperceptions" of product safety. Spence (1977) shows that a regime of no liability will not induce the socially-optimal level of care in a competitive market if consumers over- or under-estimate safety, whereas a regime of strict liability will do so. Polinsky and Rogerson(1983) show that if sellers have monopoly power and consumers over-estimate safety, then negligence is superior to strict liability because consumers will buy more output under negligence. Our consumers will not misperceive care and/or realized product safety in equilibrium, but nevertheless the level of care will be affected by the fact that they cannot observe care and/or realized safety directly.
} 
2) is it possible for the informed firm to credibly communicate such information to the consumer in either the form of an ex ante disclosure or warning or an ex post product recall or warning? Below we subdivide this section into a discussion of results when firms: 1) choose unobservable care prior to sale (that is, $\mathrm{x}$ is only known to the firm; Section 3.1 ); 2) choose observable care but also obtain other relevant information prior to sale (such as the realized likelihood of harm; Section 3.2); and 3) choose an observable level of care prior to sale but only learn the safety of the product (such as the realized level of harm, denoted $\mathrm{h}^{\mathrm{R}}$ ) after sale has occurred (Section 3.3).

\subsection{Care Is Unobservable to Consumers and Unverifiable to a Court}

In this subsection, we maintain all of the assumptions of the idealized model in Section 2 except that we relax the assumption (A1) that care is observable to the consumer prior to purchase and verifiable by a court ex post. Rather, we assume that care - beyond a minimum level denoted $\mathrm{x}_{\min }-$ is not observable to the consumer ex ante and is not verifiable by a court ex post. Thus, voluntary (contractual) transfers between the firm and the consumer (such as prices or stipulated damages) cannot be made contingent on the level of care, since a court will be unable to enforce such contractual transfers. Moreover, the court will not be able to compel transfers (such as liability payments) contingent on the level of care; thus liability-related transfers will be based on the occurrence of harm. ${ }^{8}$ In this informational environment, the appropriate comparison is between a regime of no liability and a regime of strict liability.

Since consumers cannot observe the firm's level of care directly, the price the firm receives will be independent of the actual level of care it takes; rather, the price will be based on the

\footnotetext{
${ }^{8}$ Having observed that a product caused a plaintiff's harm, it is often difficult to assess retrospectively the level of care that was taken. Even if documentation regarding the product's design (such as blueprints) is available, there may be other care-related intervening factors (such as how much care was taken in implementing the design) that affect the likelihood of harm. Therefore, the occurrence of harm is not sufficient to infer the level of care.
} 
consumer's conjectured care level, denoted $\hat{x}$. Because the market does not reward the firm for taking more care, it will choose the minimal care level, $\mathrm{x}_{\min }$. Consumers with rational expectations will therefore conjecture that $\hat{\mathrm{x}}=\mathrm{x}_{\min }$, and these expectations will be fulfilled. ${ }^{9}$ A regime of no liability provides minimal incentives for care-taking and performs quite poorly in this informational environment. Since a regime of strict liability does reward the firm for taking more care, we find that (unless litigation costs are extremely high) strict liability is preferred to no liability.

For simplicity, in the following formal analysis, we will also assume that the consumer wants at most a single unit of the good. If the consumer's conjectured care level is $\hat{x}$, then she is willing to pay $\mathrm{p}(\hat{\mathrm{x}})=\alpha-\mathrm{u}(\hat{\mathrm{x}})$ for a unit of the good under a liability regime resulting in expected uncompensated losses of $\mathrm{u}(\hat{\mathrm{x}})$. Then the firm makes a (per-unit) profit of $\alpha-\mathrm{u}(\hat{\mathrm{x}})-[\mathrm{v}(\mathrm{x})+\mathrm{c}(\mathrm{x})]$, where $\mathrm{x}$ is the firm's true choice of care.

Under no liability, $\mathrm{u}(\hat{\mathrm{x}})=\mathrm{h}(\hat{\mathrm{x}})$ and $\mathrm{v}(\mathrm{x})=0$, so the firm chooses $\mathrm{x}$ to minimize its unit production $\operatorname{cost} \mathrm{c}(\mathrm{x})$, resulting in $\mathrm{x}=\mathrm{x}_{\min }$. Since the firm cannot charge a higher price for more care, it has minimal incentives to take care. Under strict liability, the consumer may still face some uncompensated losses but, in the best-case scenario wherein the firm is liable for all harm and all litigation costs, then $\mathrm{u}(\hat{\mathrm{x}})=0$ and $\mathrm{v}(\mathrm{x})=\mathrm{h}(\mathrm{x})+2 \mathrm{k}(\mathrm{x})$. This leads the firm to minimize $\mathrm{FMC}^{\mathrm{SL}}(\mathrm{x})=$ $\mathrm{h}(\mathrm{x})+2 \mathrm{k}(\mathrm{x})+\mathrm{c}(\mathrm{x})$, and results in the care level previously denoted as $\overline{\mathrm{x}}^{\mathrm{SL}}$. Thus, a regime of strict liability with perfect compensation provides substantially stronger incentives for care.

Although it is always possible for very high expected litigation costs to render strict liability socially inferior to no liability, the information problem described in this section makes a strong case

\footnotetext{
${ }^{9}$ This is a version of the "market for lemons." See Akerlof's (1970) model in the context of a used car market, wherein market failure arises due to adverse selection. If buyers cannot verify the quality of a used car, they will only be willing to pay based on the expected quality; as a consequence, under certain conditions only "lemons" will be offered for sale.
} 
in favor of using strict liability to improve incentives for care. Indeed, the firm itself will prefer a regime of strict liability if $\mathrm{FMC}^{\mathrm{SL}}\left(\overline{\mathrm{x}}^{\mathrm{SL}}\right)<\mathrm{FMC}^{\mathrm{NL}}\left(\mathrm{x}_{\min }\right)$. The possibility of voluntary or contractual liability is considered in Section 5 below.

\subsection{When the Firm Knows the Level of Safety Prior to Sale}

In this subsection, we revert to assuming that care is directly observable by the consumer, but we assume that the firm possesses a different kind of private information. In particular, we assume that the firm learns the realized safety level (specifically, the realized likelihood that the product will cause harm), while the consumer does not. ${ }^{10}$ For simplicity, we assume that the firm and consumer have common knowledge about the extent of harm, should it occur.

When the firm is privately informed about the true level of safety of the product prior to sale, there may be channels through which such information can be communicated to consumers. If credible disclosure (or third-party certification) of the information is sufficiently inexpensive, then this avenue would be appealing to a firm producing a very safe product as a means of distinguishing its product from those that might be less safe. However, if credible disclosure is either not possible or very expensive, then the firm's actions in the market might "signal" the information to the consumer. In what follows we first consider signaling via price (relying on the monopoly model in Daughety and Reinganum, 1995) and then we return to a discussion of disclosure. Thus, in this subsection we revert to the model described in Section 2 but we relax assumption A2.

\subsubsection{Signaling}

Assume that it is not possible for a firm to credibly claim that it produces a high-safety

\footnotetext{
${ }^{10}$ On an ex ante basis, the distribution of the (random) safety level is influenced by the level of care, $\mathrm{x}$, so that higher care is likely to lead to a higher likelihood of safe use of the product (safety level), but we are focusing now on the interim time period which begins just after the firm has learned the realized safety level and continues until the consumer purchases are finalized. It is during this time period that the firm has private information relative to the consumer.
} 
product (that is, a product with a low likelihood of causing harm). This may be due to the complexity of transmitting such information to consumers, or the ease with which low-safety products might readily make such claims, or the fact that third-party certifiers either do not exist or are not themselves sufficiently credible to be able to provide such services at a cost that the productproducing firm finds profitable to employ. While there might be a number of channels through which a high-safety product might "signal" its attribute (such as advertising or warranties), the simplest one-period model is one involving signaling safety via price. ${ }^{11}$ Price can serve as a signal of safety because full marginal cost varies with safety; whether a safer product is associated with a higher or a lower price depends on the liability regime in place.

Under no liability, a firm's full marginal cost involves only its unit production cost; it is plausible to assume that marginal production cost is higher for a safer product. In this case, the equilibrium price is an increasing function of safety; moreover, the equilibrium price is distorted upward (as compared to the full-information price). Under strict liability, a firm's full marginal cost also involves its marginal liability cost, which is presumably lower for a safer product. Indeed, to provide the starkest contrast, suppose that under strict liability the firm's full marginal cost is lower for a safer product. In this case, the equilibrium price is lower for a safer product; moreover, the equilibrium price is distorted downward (as compared to the full-information price).

Since the price is upward-distorted under no liability, fewer units of the product are sold than under full information, while under strict liability more units of the product are sold than under full information. Thus strict liability has the additional salutary effect of expanding output in the market

\footnotetext{
${ }^{11}$ There are several articles in the industrial organization literature that deal with price (and other instruments) as a signal of quality. The articles cited in this subsection contain extensive references to this literature.
} 
(as compared to no liability). ${ }^{12}$ In Daughety and Reinganum (1995), we model care-taking as the sequential search for a product design; the returns to search depend in part on the number of units the firm expects it will sell in the market, so strict liability provides greater incentives to search for safer product designs. ${ }^{13}$ This interaction between two important aspects of market performance the provision of safety and the provision of output - will be discussed in detail in Section 4 .

We now describe the signaling scenario for two safety levels; we then illustrate how the results extend to a continuum of types. If we ignore liability concerns for a moment, then the only costs a firm faces are the costs of production, so a firm that wishes to signal that it produces a highsafety product will naturally price higher than would one producing a low-safety product. However, in general, this will not be enough, as it could readily be profitable for the low-type product (here "type" is shorthand for the safety of the product the firm can produce) to "mimic" the high-type product by posting the same price. The high-type product may be able to defeat this mimicry (and thereby successfully communicate its type to consumers) if it further increases its price to a point where the low-type product would not wish to imitate it. The reason this can occur is that when the firm increases its price it gives up sales: the quantity demanded of the product falls as the price rises. Thus, if there is a high enough price such that the low-type product would rather price as a low type (and get a larger volume of sales) than mimic the high type, then the high-type product can, by charging such a price, distinguish itself from the low-type product in the marketplace (when this occurs we say that the types are "revealed" or "separated"). Of course, the high-type product's

\footnotetext{
${ }^{12}$ Technically, this result holds provided that litigation costs are not too large, since full marginal costs are lower under no liability than under strict liability (where there are litigation costs in addition to the costs of production and harm).

${ }^{13}$ Since the expenditure on care is an ex ante investment rather than a contemporaneous expenditure per unit of output, the analysis of care-taking in Daughety and Reinganum (1995) also relaxes assumption A4.
} 
profits using the upward-distorted price (which allows it to be properly identified) must exceed those that would obtain if it chose its optimal price while being misperceived as the low-type product.

Now let us bring liability considerations back into the model; suppose that a substantial portion of the total loss is allocated to the firm. There may be some residual uncompensated losses for the consumer (such as costs of litigation or losses due to bargaining frictions), but the firm's marginal cost now includes both production and liability costs. While production costs rise with the safety level, expected liability costs fall as the safety level increases. When this happens it is possible for the high-type product to have lower full marginal cost than the low-type product; in this case, it is natural for the high-type product to price lower than the low-type product. However, again a low-type product is tempted to mimic the high-type product's full-information price in order to be taken to be the high type, so the high-type product must distort its price away from its fullinformation level in order to deter mimicry. In this case, however, the direction of the distortion is downward: a high-type product can afford to take on more exposure (by selling a larger volume of output) because it knows it faces a lower likelihood of having to pay liability costs in the future.

These arguments can be extended to a continuum of possible safety levels, as in Daughety and Reinganum (1995); Figure 1 below is drawn from that article.

Place Figure 1 about here

The two diagrams in Figure 1 illustrate the extreme alternatives of no liability for harm for 
the firm and strict liability for harm for the firm. ${ }^{14}$ First, consider the diagram on the left, wherein the firm bears no liability for harm. The only cost that the firm bears is that of producing the product, and we assume that a higher safety level is associated with a higher unit cost of production. The horizontal axis reflects the possible safety levels of the product, assumed to vary continuously from the lowest level of interest to the highest level. Assuming the usual linear demand function employed in earlier sections, this means that under full information (FI) a monopoly firm would charge a price that followed the price path illustrated by the rising line (in the diagram on the left) which is labeled "full info." The resulting prices would range from a low price of $\mathrm{p}_{\mathrm{L}}^{\mathrm{FI}}$ (for the lowest safety-level product) to a high price of $\mathrm{p}_{\mathrm{H}}^{\mathrm{FI}}$ (for the highest safety-level product). As implied by the earlier discussion, under asymmetric information (AI) a separating equilibrium will generally require that the price of each increasingly-higher type of product will be distorted upwards from its fullinformation price. Only the lowest type will charge its full-information price (hence, $\mathrm{p}_{\mathrm{L}}^{\mathrm{AI}}=\mathrm{p}_{\mathrm{L}}^{\mathrm{FI}}$ ), since the lowest type is deterred in equilibrium from charging a higher price and $\mathrm{p}_{\mathrm{L}}^{\mathrm{FI}}$ is its profitmaximizing price given that it is correctly-inferred to be the lowest type. With a continuum of possible safety levels, the extent of distortion is increasing in the level of safety of the product, but at a diminishing rate, as illustrated by the curved line labeled "asymmetric info." Thus, with no liability, a monopolist signals type through an upward distortion in price, with a higher price signaling a higher safety level. The diagram on the right in Figure 1 illustrates what happens when a substantial portion of the total loss is allocated to the firm. When this happens it is possible for

\footnotetext{
${ }^{14}$ Note that the two diagrams are meant to be suggestive and the location of the price points in one diagram are not meant to be compared with the location of the price points in the other diagram; within a diagram the relative locations are meaningful. In particular, between the two diagrams, the cost of production will be the same, so the cost of producing a high-safety product has not decreased from the left-hand-diagram to the right, but to make the diagrams accurate in this sense would distort the diagram on the right.
} 
full marginal cost (the sum of all these costs) to actually fall as the safety level rises. In this case not only do both price schedules decline, but the distortion in pricing is downward, as illustrated in the diagram on the right in Figure 1.

There is an additional effect of the liability regime that operates through the equilibrium price. In a regime of no liability pricing is upward-distorted, resulting in reduced sales of highersafety products (relative to the full-information monopoly outcome), while in a regime of strict liability downward-distortion of pricing means increased sales of higher-safety products (relative to the full-information outcome). That is, the allocation of liability affects the activity level (q). Furthermore, as shown in Daughety and Reinganum (1995), no liability increases the incentives for the firm to reduce production costs (at the expense of product safety) while strict liability increases the incentives to reduce liability-related costs (at the expense of higher marginal production costs).

\subsubsection{Disclosure}

The previous subsection assumes that it is not possible (or, alternatively, that it is prohibitively expensive) for a firm to disclose its realized safety level in a credible fashion prior to sale. Alternatively, if disclosure or third-party certification is not prohibitively costly, then a firm might resolve the informational asymmetry prior to sale. There is a vast literature in the economics of industrial organization on the disclosure of product quality; we will not try to review this literature in detail here, but we will summarize a few results from this literature that are relevant to products liability. The earliest work on disclosure assumes that it is costless and credible and that production costs are either zero or independent of the product's level of quality; early articles include Grossman (1981) and Milgrom (1981). The basic result in this literature is that every quality type will disclose ("unraveling") because the highest-quality product will disclose, and then the 
next-highest, on down, as this will allow them to charge a higher price to consumers who value quality. Thus, voluntary disclosure is optimal and regulation is unnecessary. If disclosure is costly (see, e.g., Viscusi, 1978 and Jovanovic, 1982), then those who will profit most from the disclosure will do so (the higher-quality types), and the lower-quality types will choose not to disclose, raising a possible argument for market intervention. Matthews and Postlewaite (1985) and Shavell (1994) consider the more complex case wherein a firm can choose whether to acquire information about the quality of its product. In this context, a mandatory disclosure rule can discourage information acquisition. Re-interpreting "quality" as product safety, we can view this previous literature as providing an analysis of disclosure in a regime of no liability. Polinsky and Shavell (forthcoming) have extended the analysis of information acquisition and disclosure to incorporate regimes of strict liability and negligence. Under negligence the firm will meet the due care standard, so the results involving information acquisition and disclosure will be the same as under no liability. Under a regime of strict liability (with perfect compensation), mandatory and voluntary disclosure are equivalent with respect to information acquisition since consumers do not care about (or respond to) the disclosure of product risks. In this case, a firm's profit-maximizing choice regarding information acquisition simply reflects the value of information for the purpose of forecasting future liability costs.

When compensation is not perfect then consumers do care about product safety. Furthermore, if production cost is increasing in the safety level of the product, as we have earlier argued, then a monopolist will want to "communicate" its private information (its safety level) to consumers, and this too will affect welfare. Given the distortion in prices shown in Figure 1, firm profits will also be distorted away from the full-information levels, so that as this distortion grows, 
the benefit from paying for (say) a credible third-party disclosure process will grow until (for some intermediate type of product safety), it may be profitable for the firm to switch from signaling via price to paying for costly (but credible) disclosure. Note that in the case wherein price is upwarddistorted, this will make price fall (for all types who disclose) to the full-information level, increasing sales and welfare. When price is downward distorted, the reverse can happen; disclosure can cause welfare to fall, since now price will rise to the full-information level for those types who pay for credible disclosure (see Daughety and Reinganum, 2008a,b, for details).

\subsection{The Firm Has Post-Sale Private Information}

In this section, we revert to the idealized model in Section 2 where care is taken on a per-unit basis, the consumer can observe the firm's level of care prior to purchase of the good, and the firm does not have private information prior to sale. However, we now assume that the firm observes the realized level of harm post-sale (that is, we relax assumption A3); for simplicity, we assume that this new information is received before any harms occur. ${ }^{15}$ It is straightforward to show that under a regime of no liability a firm has no incentive to reveal to consumers its (post-sale) new information, even though consumers - if warned - could avoid using the product and suffering the associated harm. On the other hand, either a negligence-based liability rule (post-sale duty to warn) or strict liability will induce the firm to issue a warning when the realized harm is sufficiently high. Which of these rules is best depends on the cost of warnings; we provide a brief formal analysis below. ${ }^{16}$

\footnotetext{
15 Obviously, this is an over-simplification since the firm is most likely to learn the likelihood and magnitude of harm from the reports and complaints of harmed consumers. Nevertheless, in many cases prompt action on the part of the firm may be able to prevent substantial further injuries from occurring, and this is what we capture in our assumed timing.

16 These arguments are based on Spier (forthcoming), who uses a more general model; in particular, consumers have different values for the good, so it is socially efficient for some consumers to use the product and for others to discard it. In our simplified model, either all consumers should use it or all should discard it. Spier also uses a fixed cost of issuing a warning, while we will incorporate these as costs per consumer in keeping with the rest of the cost specification. See also Ben-Shahar (1998), which explores the effects of liability rules based on "hindsight;" such rules
} 
Since the volume of output will not be of primary concern in this section, we assume that each consumer wants at most one unit of the good. The firm's level of care is observable to the consumer and there is no private information prior to the consumer's purchase of the good, so her willingness-to-pay for a unit is simply $\mathrm{p}(\mathrm{x})=\alpha-\mathrm{u}(\mathrm{x})$, where $\mathrm{u}(\mathrm{x})$ is the consumer's expected uncompensated loss (which will ultimately vary with the liability regime). Thus, in the initial market transactions with $\mathrm{N}$ consumers, the firm obtains profit of $\Pi(\mathrm{N}, \mathrm{x})=[\alpha-\mathrm{u}(\mathrm{x})-\mathrm{v}(\mathrm{x})-\mathrm{c}(\mathrm{x})] \mathrm{N}$.

Now suppose that, after having sold the product to the consumers, the firm learns the realized harm $\mathrm{h}^{\mathrm{R}}$; that is, the firm learns that every unit will cause harm $\mathrm{h}^{\mathrm{R}}$ when used by the consumer. We will compare the regimes of no liability, post-sale duty to warn, and strict liability in terms of their avoidance of harm, incentives to take care, firm profits, and welfare.

If the firm faces no liability, then it will do nothing despite its superior information about harm; anticipating this, the consumer deducts the expected harm $\mathrm{h}(\mathrm{x})$ from her willingness-to-pay for the good. Thus, the firm's equilibrium payoff under no liability is $\Pi(N, x)=[\alpha-h(x)-c(x)] N$, and its level of care will be $\overline{\mathrm{x}}^{\mathrm{NL}}$. Although it would be socially efficient to avert some accidents (even if this entails some cost, as will be assumed below), this will not happen under no liability.

Now suppose that the firm could issue a warning at a per-consumer cost of w; that is, it could credibly inform a consumer (who has already purchased the product) of the realized value $\mathrm{h}^{\mathrm{R}}$ by paying the cost $\mathrm{w}$. It would be socially efficient for the firm to warn the consumer not to use the product whenever the realized harm $\mathrm{h}^{\mathrm{R}}$ exceeds the foregone value of consumption plus the warning cost: that is, whenever $\mathrm{h}^{\mathrm{R}}>\alpha+\mathrm{w}$. Consider the effect of a liability regime wherein the firm faces a duty to warn the consumer if it learns that $h^{R}>\alpha+w$, and so doing exempts the firm from 
compensating consumers who use the product despite the warning and are subsequently injured. Under this rule, a consumer who is warned that $\mathrm{h}^{\mathrm{R}}>\alpha+\mathrm{w}$ will optimally discard the product (since she would enjoy $\alpha$ in consumption value but would bear the greater harm $\mathrm{h}^{\mathrm{R}}$ ). Furthermore, suppose that if the firm fails to warn, then it is responsible for the consumer's harm and her (realized) litigation $\operatorname{cost} \mathrm{k}^{\mathrm{R}}$, where $\mathrm{k}^{\mathrm{R}}$ reflects the actual cost of a lawsuit, given that a harm has occurred. Then the firm that learns that $h^{R}>\alpha+w$ will pay $h^{R}+2 k^{R}$ if it fails to warn and $w$ if it warns, so it will warn whenever $\mathrm{h}^{\mathrm{R}}>\alpha+\mathrm{w}$ as long as $\mathrm{h}^{\mathrm{R}}+2 \mathrm{k}^{\mathrm{R}}>\mathrm{w}$. Notice that $\mathrm{h}^{\mathrm{R}}>\alpha+\mathrm{w}$ implies that $\mathrm{h}^{\mathrm{R}}+2 \mathrm{k}^{\mathrm{R}}>$ $\mathrm{w}$, so the firm will indeed warn whenever it learns that $\mathrm{h}^{\mathrm{R}}>\alpha+\mathrm{w}$, and the consumer will discard the product when warned. This rule averts accidents that are associated with higher levels of harm.

Under this rule, the consumer expects that she will be warned when the firm learns that $\mathrm{h}^{\mathrm{R}}$ is high (above $\alpha+\mathrm{w}$ ) and then she will discard the product (losing the consumption value $\alpha$ ), while she will not be warned when the firm learns that $\mathrm{h}^{\mathrm{R}}$ is low (below $\left.\alpha+\mathrm{w}\right)$. In this latter case, we assume that she uses the product when not warned, and bears the associated loss. Her expected uncompensated loss is $\mathrm{u}(\mathrm{x})=\alpha \operatorname{Pr}\left\{\mathrm{h}^{\mathrm{R}}>\alpha+\mathrm{w} \mid \mathrm{x}\right\}+\operatorname{Pr}\left\{\mathrm{h}^{\mathrm{R}} \leq \alpha+\mathrm{w} \mid \mathrm{x}\right\} \mathrm{E}\left(\mathrm{h}^{\mathrm{R}} \mid \mathrm{h}^{\mathrm{R}} \leq \alpha+\mathrm{w}, \mathrm{x}\right)$. The firm will anticipate paying the expected costs of warning, $\mathrm{v}(\mathrm{x})=\mathrm{w} \operatorname{Pr}\left\{\mathrm{h}^{\mathrm{R}}>\alpha+\mathrm{w} \mid \mathrm{x}\right\}$, and its expected profits are $\Pi(N, x)=[\alpha-u(x)-v(x)-c(x)] N$. Notice that $u(x)+v(x)<h(x)$ since the righthand-side includes values of $h^{R}>\alpha+w$, while the sum $u(x)+v(x)$ substitutes the value $\alpha+w$ when $\mathrm{h}^{\mathrm{R}}>\alpha+\mathrm{w}$, reflecting the fact that high realized harms are averted by warnings. As long as the worst possible harm exceeds $\alpha+\mathrm{w}$, this version of duty to warn is socially-preferred to no liability.

Finally, consider the regime in which the firm is strictly liable for harm to the consumer; again, for simplicity, assume that her litigation costs are also compensated. Since the consumer is fully-insured $(\mathrm{u}(\mathrm{x})=0)$, she is willing to pay $\alpha$ for the product ex ante, and she will continue to use 
it ex post. In order to avert harm ex post, the firm must buy back the product from the consumer at a price of $\alpha$. Assume that the cost of initiating a buyback is $\mathrm{w}$ (the same as the cost of a warning); then the firm will buy back the product whenever $h^{R}+2 k^{R}>\alpha+w$. Conditional on the strict liability regime, this is also the socially-efficient buyback threshold. ${ }^{17}$ The firm's expected liability plus buyback costs are given by $\mathrm{v}(\mathrm{x})=\operatorname{Pr}\left\{\mathrm{h}^{\mathrm{R}}+2 \mathrm{k}^{\mathrm{R}}>\alpha+\mathrm{w} \mid \mathrm{x}\right\}(\alpha+\mathrm{w})+\operatorname{Pr}\left\{\mathrm{h}^{\mathrm{R}}+2 \mathrm{k}^{\mathrm{R}} \leq \alpha+\mathrm{w} \mid\right.$ $\mathrm{x}\} \mathrm{E}\left(\mathrm{h}^{\mathrm{R}}+2 \mathrm{k}^{\mathrm{R}} \mid \mathrm{h}^{\mathrm{R}}+2 \mathrm{k}^{\mathrm{R}} \leq \alpha+\mathrm{w}, \mathrm{x}\right)$. The firm's profits are given by $\Pi(\mathrm{N}, \mathrm{x})=[\alpha-\mathrm{v}(\mathrm{x})-\mathrm{c}(\mathrm{x})] \mathrm{N}$.

Notice that if (counterfactually) the litigation $\operatorname{cost} \mathrm{k}^{\mathrm{R}}$ were zero, then the firm's profits under duty to warn and under strict liability would coincide and thus both would be superior to no liability. However, as the litigation cost parameter increases from zero, the firm's expected liability costs increase under strict liability, but this has no effect on the analogous term under duty to warn. Thus, for moderate values of litigation costs, firm profits and social welfare are highest under duty to warn, next highest under strict liability, and lowest under no liability. However, it is possible that litigation costs could be high enough for strict liability to become worse than no liability.

In summary, when the firm can be expected to learn more about harm in the post-sale environment, then it will be preferable to use some form of liability to encourage it to take steps to avert some harm that would otherwise occur. The best such rule is a negligence-based one (duty to warn) but, if this is viewed as being too information-intensive, strict liability would also improve welfare provided that litigation costs are not too high.

\section{Investment in the Level of Care}

We now consider what happens to the results of Section 2 with a more general model of how

\footnotetext{
17 Spier (forthcoming) assumes heterogeneous willingness-to-pay. Since the firm is a monopsonist in buying back the good, it sets too low a price and sometimes does not initiate a recall when it should. Here, all consumers are alike so the firm must pay the buyback price $\alpha$ to all of them, resulting in the efficient use of buyback (given the liability regime). Other papers that examine the use of recalls and buybacks include Welling (1991), Marino (1997), and Hua (2011).
} 
investment in care level affects: 1) the choice of this level by the firm; 2) the socially-optimal choice of care level; and 3) a court's ability to apply alternative liability regimes. Why is a more general model desirable? The reason is that in many important industries which produce products with substantial attendant safety issues, the simple model of a firm's cost used in Section 2 as being the product of a per-unit cost $(\mathrm{c}(\mathrm{x}))$ times the number of units (q) misses an important activity of the firm: safety investment that is independent of the level of output. ${ }^{18}$ For example, industries such as pharmaceuticals, automobiles, and aircraft manufacture (especially commercial aircraft) incur safety-related research and development (R\&D) expenses that are substantial, are driven by prospectively-available profits, and (while made in anticipation of production) are not proportional to the level of output (as is assumed by the model in Section 2). As a specific example, a 2006 CBO report ${ }^{19}$ indicates that the average length of clinical trials and FDA approval needed for new drugs (referred to as new molecular entities, so as to distinguish these from drugs which are small modifications of existing products) is on the order of 7.5 years, with an overall development horizon of over 11.8 years and a total cost (in 2000-dollars) of over 800 million dollars. Much of this involves testing so as to assess and possibly re-engineer the safety level of the drug in question.

In economic theory such investment costs are referred to as "endogenous fixed costs:" costs which do not depend on actual levels of output but which are incurred by a firm as a reflection of

\footnotetext{
18 The idealized model involves very strong assumptions. The demand function in Section 2 is "additively separable" in $\mathrm{q}$ and $\mathrm{x}$ (see equations (1) and (2)); the cost function is "multiplicatively separable" in q and $\mathrm{x}$ and, moreover, it reflects constant returns-to-scale in that it is linear in output (see A4). Spence (1975) showed that if the demand function is not additively separable, then a firm will generally not choose the socially-efficient level of x. Spulber (1989) observes that if the firm's cost function does not reflect constant returns-to-scale, then again a firm's choice of $\mathrm{x}$ will not generally be the socially-efficient level. Here, we allow the demand function to be additively separable and the variable production cost to be constant returns-to-scale (as in Section 2) but by allowing for (endogenously-determined) safety investment costs to be independent of output we produce an overall cost function for the firm which is not constant returns-to-scale. Once this occurs, market structure influences the incentives created by the liability regime.

${ }^{19}$ See especially pages 19-21 for discussion and qualifications of these estimates.
} 
an endogenously-determined investment decision made by the firm to make production of a given quality or type of good possible and profitable. The first comprehensive treatment of this concept appears in Shaked and Sutton (1987) and is further developed and summarized in an extensive and detailed theoretical and empirical treatment in Sutton (1991). In the law and economics literature on torts four analyses have incorporated endogenous fixed costs (Daughety and Reinganum,1995 and 2006, where the investment is in R\&D related to product safety, and Arlen and MacLeod, 2003, and Arlen, 2010, where the investment is in medical expertise). In this section we summarize and amplify the results of Daughety and Reinganum (2006) as it most explicitly develops the implications of endogenous fixed costs for products liability; the other two papers are discussed in more depth in other parts of this review.

\section{Overview of Results}

In what follows we provide a simple duopoly (two-firm) model to allow for competition between the firms over their (differentiated) products; Daughety and Reinganum (2006) allow for a more general model with $\mathrm{n}$ firms, and we will provide a brief discussion of what happens as the number of firms grows and as the closeness of products (their "substitutability in consumption") adjusts; both of these attributes of the market allow us to understand firm response to liability as the degree of competition changes. As we shall see, this seemingly small "technical" modification of the model in Section 2 radically changes the traditional model's results. In particular: 1) under strict liability firms, in general, will not independently choose the socially-efficient level of care and 2) courts employing a negligence standard will face a substantially more difficult, and more information-intensive, process of determining the efficient level of the standard to set than is usually suggested in the typical law and economics treatment. 


\subsection{A Two-Period, Two-Firm Model of Investment in Care under Strict Liability}

We incorporate competition into the analysis by modifying the earlier willingness-to-pay function for the consumer, $\mathrm{p}(\mathrm{q} ; \mathrm{x})$, to account for there being two firms, each of which produces a product for the same market; the two products are differentiated and therefore are imperfect substitutes for one another. ${ }^{20}$ More precisely, firm $\mathrm{i}(\mathrm{i}=1$ or 2$)$ produces product $\mathrm{i}$, so anything with a subscript $i$ reflects that firm's product. Thus, $x_{i}$ is firm $i$ 's level of care and $q_{i}$ is the amount of product $i$ that the consumer purchases at price $\mathrm{p}_{\mathrm{i}}$, but now we must allow for the consumer to buy a substitute product as well. Therefore, when also buying an amount of product $\mathrm{j}$, denoted as $\mathrm{q}_{\mathrm{j}}$, we allow the consumption of the substitute product $\mathrm{j}$ to influence the willingness-to-pay for product $\mathrm{i}$ : $\mathrm{p}_{\mathrm{i}}\left(\mathrm{q}_{1}, \mathrm{q}_{2} ; \mathrm{x}_{\mathrm{i}}\right)$ denotes the consumer's willingness-to-pay (inverse demand) for another unit of product $i$ when she consumes $q_{i}$ units of product $i, q_{j}$ units of product $\mathrm{j}$ and firm i's level of care is $\mathrm{x}_{\mathrm{i}}$, for $\mathrm{i}=1,2$.

This inverse demand function will be taken to be a direct extension of that employed in Section 2:

$$
\mathrm{p}_{\mathrm{i}}\left(\mathrm{q}_{1}, \mathrm{q}_{2} ; \mathrm{x}_{\mathrm{i}}\right)=\alpha-\mathrm{u}\left(\mathrm{x}_{\mathrm{i}}\right)-\beta \mathrm{q}_{\mathrm{i}}-\gamma \mathrm{q}_{\mathrm{j}}, \quad \text { with } \mathrm{i}=1,2 ; \mathrm{j}=1,2 ; \mathrm{i} \neq \mathrm{j} \text {. }
$$

Thus, the parameter $\beta$ (respectively, $\gamma$ ) measures the effect that consuming more of product $\mathrm{i}$ (respectively, product $\mathrm{j}$ ) has on the willingness-to-pay for product i. Furthermore, the parameter $\gamma$ captures the degree to which the two products are treated by the consumer as substitutes; if $\gamma$ is zero then product $\mathrm{j}$ has no effect on the willingness-to-pay for product $\mathrm{i}$ (the products are called "independent" so each firm can act as a monopolist in its sub-market), while if consumption of product $\mathrm{j}$ had the same effect on willingness-to-pay as consumption of product $\mathrm{i}$, then the products

\footnotetext{
20 When economists speak of goods being imperfect substitutes what this means intuitively is that two goods are (typically) differentiated by some characteristic (other than care level x), so that small price changes or small changes in the care level do not cause consumers to shift all of their consumption from one good to the other. Technically, consumer preferences are smooth and convex in the two goods.
} 
would be called "perfect substitutes" and this would be captured by having $\gamma=\beta$. Formally, we will assume that $\gamma$ can take on values between (and including) zero and $\beta$, so that the ratio $\gamma / \beta$ provides a convenient measure of the degree to which the products are (imperfect) substitutes; when it is zero the goods are viewed by consumers as independent while when it is one consumers view the products as perfect substitutes (for example, two brands of generic aspirin). In what follows we will refer to $\gamma$ as the "substitution" parameter and $\gamma / \beta$ as the "relative substitution ratio."

This model captures the essence of strategic interaction between the two firms via the sales of their two products: from each firm's viewpoint, strategic interaction occurs via their revenue functions, since for firm i revenue is $\mathrm{p}_{\mathrm{i}}\left(\mathrm{q}_{1}, \mathrm{q}_{2} ; \mathrm{x}_{\mathrm{i}}\right) \mathrm{Nq}_{\mathrm{i}}$. Notice that we have simplified the model to exclude firm-specific effects on the parameters $(\alpha, \beta$, or $\gamma)$ or on the functions which capture costs to the firm or consumer (c, v, and u). Generalizing the model to allow for such firm-specific effects is possible, of course, but then intuitively-reasonable graphical description of the results would not be possible. Note also that such demand functions assume that all consumers: 1) are the same; and 2) consume some amount of every product, though the quantities in a consumer's optimal bundle reflect the prices and the safety characteristics of all the goods offered for sale in the market.

Now, rather than viewing care as contributing only to variable costs, we explicitly assume that it generates an investment cost per unit of care as well, so that equation (1) is now modified to become the following:

$$
\Pi_{\mathrm{i}}\left(\mathrm{Nq}_{1}, \mathrm{Nq}_{2} ; \mathrm{x}_{\mathrm{i}}\right)=\left[\mathrm{p}_{\mathrm{i}}\left(\mathrm{q}_{1}, \mathrm{q}_{2} ; \mathrm{x}_{\mathrm{i}}\right)-\mathrm{v}\left(\mathrm{x}_{\mathrm{i}}\right)-\mathrm{c}\left(\mathrm{x}_{\mathrm{i}}\right)\right] \mathrm{Nq}_{\mathrm{i}}-\mathrm{Tx}_{\mathrm{i}}, \quad \mathrm{i}=1,2,
$$

where the functions $\mathrm{v}$ and $\mathrm{c}$ are as before, but $\mathrm{T}$ is now the per-unit-of-care cost that the firm incurs when it engages in investment in safety design. As suggested above, the amount $\mathrm{Tx}_{\mathrm{i}}$ is likely to be 
large in industries with products that have substantial safety attributes. ${ }^{21}$

It is natural to think of the investment choice as being of a longer-run nature than the outputlevel choice, so to find the equilibrium levels of care and the equilibrium levels of output for each product we model the decisions as occurring in two stages: in the first stage each firm $i$ chooses its level of investment in care, $\mathrm{x}_{\mathrm{i}}$, anticipating that in the second stage all firms will choose their individual output levels with knowledge of the chosen care levels for each firm. The solution to this problem involves finding the equilibrium output levels for each firm. The equilibrium output levels are rather complicated functions of the parameters (and the investment levels for each of the firms), so we suppress them here (see Daughety and Reinganum, 2006, p. 308). However, it is useful to note that, holding the other firm's care level fixed, an increase in firm i's care level will result in an increase in firm i's equilibrium output level and a decrease in firm j's equilibrium output level. This is because consumers value care (safety) and product $\mathrm{i}$ is now relatively safer that product $\mathrm{j}$. Thus, an increase in firm i's level of care allows firm $i$ to "steal business" from firm $j$.

One can show that firm i's level of care is determined in equilibrium by the following equation (that is, the following condition is the first-order-condition for firm i to choose its optimal level of care, given that both firms then choose equilibrium output levels):

$$
\mathrm{Nq}_{\mathrm{i}}\left[\mathrm{dFMC}\left(\mathrm{x}_{\mathrm{i}}\right) / \mathrm{dx}_{\mathrm{i}}\right] \quad+\quad \mathrm{Nq}_{\mathrm{i}}\left[\gamma \partial \mathrm{q}_{\mathrm{j}} / \partial \mathrm{x}_{\mathrm{i}}\right] \quad=-\mathrm{T} .
$$

Full-Marginal-Cost Effect Business-Stealing Effect

Equation (4) reflects three elements of interest. The first term is the "full-marginal-cost" effect, and is the amount of output times the derivative of the full marginal cost function (recall that $\mathrm{FMC}\left(\mathrm{x}_{\mathrm{i}}\right)$

\footnotetext{
${ }^{21}$ A further example is the inclusion of airbags in automobiles. Including an airbag increases the cost, $\mathrm{c}(\mathrm{x})$, of each automobile, but the cost (Tx) of the development work associated with inventing and testing a reliable airbag system is independent of the number of cars produced. Furthermore, as design changes are contemplated, modifications of (and advances in) the airbag system are sometimes necessitated (for example, side airbags).
} 
$\left.=\mathrm{u}\left(\mathrm{x}_{\mathrm{i}}\right)+\mathrm{v}\left(\mathrm{x}_{\mathrm{i}}\right)+\mathrm{c}\left(\mathrm{x}_{\mathrm{i}}\right)\right)$. Notice that if there were no second firm (that is, either firm $\mathrm{i}$ is a monopolist, or the two products are independent, making $\gamma$ in the second term above zero), and if first-stage investment in care were free $(\mathrm{T}=0)$, then we would get the traditional result that the firm would choose the care level $\left(\mathrm{x}_{\mathrm{i}}\right)$ that minimizes FMC (that is, where the derivative is zero). On the other hand, even if there is no other firm (or if products are independent), if there is a positive first-stage investment cost, so that $\mathrm{T}$ is not zero, then equation (4) tells us that the firm will not choose its level of care at the bottom of FMC. It will be somewhere to the left of the bottom, since T positive means that $-\mathrm{T}$ is negative, thereby requiring that the chosen value for $\mathrm{x}_{\mathrm{i}}$ make $\mathrm{dFMC}\left(\mathrm{x}_{\mathrm{i}}\right) / \mathrm{dx} \mathrm{x}_{\mathrm{i}}$ negative; that is, the choice of care occurs to the left of the minimum of FMC.

The second term in equation (4) involves the effect of an increase in firm i's care level on the quantity demanded of firm j's product, holding firm $\mathrm{j}$ 's choice of care level unchanged $\left(\partial \mathrm{q}_{\mathrm{j}} / \partial \mathrm{x}_{\mathrm{i}}\right)$. Since more safety is preferred by consumers to less, this means the derivative in the second term is negative; this is why it is referred to as a "business-stealing" effect. Notice also that the more substitutable the two products are (the larger is $\gamma$ ) then the larger is this effect. Despite the negative sign of the second effect, it can be shown that the first term is still (at equilibrium) negative as well.

This analysis generalizes directly to an arbitrary number of firms, n. Figure 2 illustrates the effect of changes in the number of firms and the relative substitution ratio $(\gamma / \beta)$ on care. Symmetry implies that the firms choose the same level of care in equilibrium, since none of the parameters or functions are firm-specific. While the Figure is meant to be suggestive rather than precise, it embodies a number of properties of the equilibrium care level which can be shown to hold. Note that the monopoly choice (denoted as $\mathrm{x}^{1}$, where the 1 reflects that there is one firm) is less than that which would have been asserted by the idealized model (with $\mathrm{T}=0$ ) to occur at the minimum of 
$\operatorname{FMC}(\mathrm{x})$; that is, at $\overline{\mathrm{x}}$. As discussed above, $\mathrm{x}^{1}$ is also the level of care that each duopolist would choose if the products were independent. The different curves drawn in the Figure show the level of care for three values of possible numbers of competitors (oligopolies of 2, 3, and 4 firms) as a function of the relative substitution ratio $\gamma / \beta$. All of these curves begin at the same level of care $\left(\mathrm{x}^{1}\right)$ since, when $\gamma=0$, each firm is a monopolist in its product; although they decline initially, as $\gamma / \beta$ continues to increase they eventually increase.

Place Figure 2 about here

To understand the behavior of the curves depicted in Figure 2, fix the number of competitors and consider any one of the three curves. To see why it is first declining and then increasing, we examine equation (4) after the equilibrium level of care (and the implied equilibrium levels of output as a function of all levels of care) has been found and re-substituted back into this condition. Recall that the first expression measures the "full-marginal-cost" effect. The oligopoly equilibrium level of care will depend on an individual firm's total anticipated output; the higher is the anticipated output, the greater is the firm's incentive to lower its full marginal cost by increasing its level of care. Consider the impact of increasing the extent of substitutability $(\gamma)$ on this first expression. As products become somewhat substitutable, each firm anticipates lower equilibrium output and this tends to reduce the equilibrium choice of care.

On the other hand, the second expression in equation (4) measures the business-stealing effect; as products become better substitutes the firm will increasingly perceive a business-stealing benefit to increasing its choice of care. It can be shown that (initially) business-stealing turns out 
to be a weak influence as compared with the FMC effect; this is because $\gamma$ is initially very small. Inasmuch as products are weak substitutes, small changes in the care level (x) do not have much of an effect on shifting demand between the products, but firm outputs are falling due to an increase in competition (as measured by $\gamma / \beta$ ) and falling output leads to lower care through the FMC effect. However, eventually the impact of increasing $\gamma / \beta$ on the FMC effect is dominated by its impact on the business-stealing effect. In order to compete for consumers, firms start to increase their levels of care, making the displayed curve turn up.

Now consider an increase in the number of firms, n, holding other parameters constant. Notice that: 1) the bottom of each curve occurs at a higher relative substitution ratio when there are more firms (the bottoms "march to the right" relative to the horizontal axis), so that it requires more substitutability of products in order for the business stealing effect to enhance the equilibrium choice of care in an industry with more firms; and 2) an increase in the number of firms in the industry for fixed $\gamma / \beta$ leads to lower equilibrium care, as each firm anticipates lower equilibrium output. ${ }^{22}$

\subsection{The Socially-Efficient Level of Care versus the Equilibrium Level of Care under Oligopoly}

We now characterize the socially-efficient level of care. An overall socially-efficient solution might consider setting efficient levels of the number of competitors, the level of care chosen, and the level of output for each firm. The fact that there are fixed costs associated with care suggests that welfare would be highest if these were incurred just once (that is, the socially-efficient choice would be for there to be a monopolist), but that neglects the fact that the demand system, and the underlying utility function that generates this demand system, reflects a consumer preference for variety; thus, one should expect that the efficient number of firms might readily exceed one.

\footnotetext{
${ }^{22}$ As the number of imperfect substitutes (n) increases, the consumer purchases a greater total amount of the imperfect substitutes (and less of the numeraire good) but each of the $\mathrm{n}$ firms sells a smaller amount of its own product.
} 
However, this begs the point; in general, no policy of thoroughly regulating all industries that produce products with safety attributes is likely to be adopted, if only because the costs of engaging in such regulation are likely to be quite high. However, we do have a "regulatory system" in place where industry size and firm output level is determined by market forces, but which sets standards for care: tort law. In what follows we will consider the socially-efficient choice of care under the assumption that both industry size and firm output are determined by market forces.

Formally, we would write the "social planner's problem" for choosing the socially-efficient level of care for firm $\mathrm{i}$, denoted as $\mathrm{X}_{\mathrm{i}}$, so as to maximize the difference between the aggregate value for the n products minus the aggregate cost, subject to the aggregate quantity produced by each firm being its equilibrium output level $\mathrm{Nq}_{\mathrm{i}}\left(\mathrm{X}_{1}, \ldots, \mathrm{X}_{\mathrm{n}}\right), \mathrm{i}=1, \ldots, \mathrm{n}$, that arises from the oligopolistic interaction of the firms (given the care levels). Again, in what follows we appeal to the fact that without firm-specific parameters and functions there will be a common equilibrium level of care for each firm (which depends upon the number of firms, $n$ ), $X^{n}$, and a common equilibrium level of output for each firm (also dependent upon the number of firms), $\mathrm{Nq}^{\mathrm{n}}$. Figure 3 displays curves for both the socially-efficient (for a given $\mathrm{n}$ and $\mathrm{q}$ as determined by market forces) level of care - the solid curves - and the market equilibrium levels - the dashed curves - for duopoly $(n=2)$ and triopoly $(n=3)$; this diagram again can be supported by more detailed mathematical analysis.

Place Figure 3 about here

\subsection{Implications for Liability Incentives and Due-Care Levels}

First, as shown in Figure 3, if there was only one firm then the socially-efficient level of care 
would be greater than the equilibrium level, but below that which minimizes FMC (as this would expand output). Second, for any given number of firms in the industry, as products become closer substitutes (as $\gamma / \beta$ grows), the socially-efficient level of care falls, and for any given extent of substitutability, more firms implies a lower per-firm level of care. Third, while the planner cannot fully-internalize the oligopolistic incentives that the firms operate under, there is no social advantage to business-stealing, so there is no reversal of direction of the curve. Note also that, as depicted, in a duopoly with products that are perfect substitutes, the equilibrium level of care is the efficient level, but otherwise it is always inefficiently low. Moreover, as is suggested by Figure 3, when there are more than two firms, there is a range of $\gamma / \beta$ such that the equilibrium is still inefficient but involves too much care (this arises because of business-stealing incentives). It can be shown that this is a general result for any given number of firms in the industry and that as this number grows the portion of the horizontal axis that is associated with excessive care increases. Overall, what one should observe is that, for any given size of an industry, there is always a unique level of the relative substitution ratio such that the market equilibrium care level is efficient; for any value below this care is inefficiently low, while for any value above this it is inefficiently high.

Under strict liability, the court need not determine a due care standard, so the court's problem is not affected by the above analysis, but we also know that the market will not produce efficient investment in care by the firms. On the other hand, in order for a court to determine the efficient level of care (say, in order to implement a negligence regime), it would need detailed information not only on $\mathrm{FMC}(\mathrm{x})$, but also on the nature of competition in the specific industry involved as well as detailed information on consumers' demand over the set of products being produced by the industry. While one could perhaps imagine a court finding the minimum of FMC 
(which would be socially efficient in the model of Section 2), the court's problem is much more challenging and information-intensive when there are fixed costs of care since the care and output decisions are entangled. ${ }^{23}$ Thus, the choice of liability regime (strict liability versus negligence) confronts us with a trade-off between a generally inefficient choice by firms (under strict liability) and a very difficult informational problem for the court (under negligence).

A comparison between no liability and strict liability is particularly complicated when there are endogenous fixed costs of care. Although strict liability provides an additional marginal incentive to increase care (since avoiding accidents avoids litigation costs as well), full marginal cost will be higher under strict liability, as it will reflect expected litigation costs. Higher FMC leads to higher prices and lower firm output, and lower anticipated firm output results in lower care in equilibrium. The net result of these conflicting incentives is likely to be highly market-dependent (that is, it will depend on the number of firms, the size of the market, the relative substitution ratio, and the unit cost of care). Moreover, it is possible for the market to over- or under-provide care under either liability regime (again, depending on the market attributes).

\section{Mandatory versus Contractual Liability}

Some scholars have argued that liability generates litigation costs that raise prices to all consumers, some of whom would not be willing to "buy" this coverage at the implied price. ${ }^{24}$ They argue that firms should be able to offer, and consumers should be able to purchase, contractual

\footnotetext{
${ }^{23}$ See Schwartz (1988) for arguments about the difficulties facing courts attempting to set standards for fault and how negligence law, applied in the products liability context, creates incorrect incentives for firms to produce safety.

${ }^{24}$ See, for example, Schwartz (1988), and Polinsky and Shavell (2010), who suggest that consumers might not purchase insurance for non-pecuniary losses. Epstein (1985) argues that voluntary liability would result in fine-tuned insurance contracts that anticipate the possibility of consumer moral hazard and adverse selection, while products liability provides a uniform policy to consumers with heterogeneous attributes and tastes.
} 
liability (starting from a default of no liability) or they should be able to agree to waive liability (starting from a default of strict liability). ${ }^{25}$ We do not claim to be comprehensive in our coverage of this issue, but some of the deviations (from the idealized model) considered above affect the feasibility, desirability, and effectiveness of individually-negotiated contractual liability.

First, reconsider the model of Section 3.1 assuming that each consumer can choose to purchase contractual liability. Recall that in this model care is unobservable to the consumer ex ante of purchase and unverifiable to a court ex post. No liability results in a care level of $\mathrm{x}_{\min }$, while strict liability (assuming no under-compensation for plaintiffs) results in a care level of $\overline{\mathrm{x}}{ }^{\mathrm{SL}}$. Although the consumer's surplus is fully-extracted under either liability regime and thus she is indifferent between them, the firm is not indifferent. Its payoff is $\alpha-\mathrm{FMC}^{\mathrm{NL}}\left(\mathrm{x}_{\min }\right)$ under no liability and $\alpha-\mathrm{FMC}^{\mathrm{SL}}\left(\overline{\mathrm{x}}^{\mathrm{SL}}\right)$ under strict liability, for each unit sold. As indicated in Section 3.1, the firm itself will prefer strict liability if $\mathrm{FMC}^{\mathrm{SL}}\left(\overline{\mathrm{x}}^{\mathrm{SL}}\right)<\mathrm{FMC}^{\mathrm{NL}}\left(\mathrm{x}_{\min }\right)$. This is quite possible since, although full marginal costs are higher under strict liability for any level of care $\mathrm{x}$, the care level $\overline{\mathrm{x}}^{\mathrm{SL}}$ minimizes $\mathrm{FMC}^{\mathrm{SL}}(\mathrm{x})$ while $\mathrm{FMC}^{\mathrm{NL}}(\mathrm{x})$ is likely to be quite high at $\mathrm{x}_{\text {min }}$ (that is, when little care is exercised).

Assume that the firm does prefer strict liability to no liability (because it will reassure the consumer that she need not worry about deducting expected uncompensated losses from her willingness-to-pay). Then the firm could demand a price of $p=\alpha-\varepsilon$, where $\varepsilon$ is a small positive

\footnotetext{
${ }^{25}$ Alternatively, Geistfeld $(1988,1994)$ and Schwartz (1988) propose that sellers quote two prices, one inclusive of strict liability and the other exclusive of liability, and allow consumers to choose their preferred policy. Consumers could simply take out private insurance policies against losses due to their use of products. Insurance companies could use market-based incentives (such as monitoring and contracting) to encourage firms to choose the optimal level of care. However, in the event of injury the consumer would now have to establish to the insurance company that the injury was caused by the product, that the product was covered under her policy, and so on. Insurance companies have the same incentives to resist payment as does the firm when the required compensation is high (for example, as in Hurricane Katrina in 2005). Moreover, it is unclear how effective insurance companies' market-based incentives would be at inducing optimal care, since these would presumably involve auditing, incentive payments, and/or information rents.
} 
number, in exchange for a unit of the product and full contractual liability. The firm will choose $\overline{\mathrm{x}}^{\mathrm{SL}}$ and receive a payoff of $\alpha-\varepsilon-\mathrm{FMC}\left(\overline{\mathrm{x}}^{\mathrm{SL}}\right)$ under contractual liability; both parties are better off by engaging in this transaction than by proceeding under no liability.

Although this seems to solve the problem of providing incentives for the firm to take more appropriate care using contractual liability, it fails to account for the fact that a contract, once negotiated, may also be renegotiated. ${ }^{26}$ It turns out that renegotiation can undermine the firm's incentives to take care. To see this, suppose that the consumer and the firm have come to an agreement involving full contractual liability as discussed above; for simplicity, let $\varepsilon$ go to zero so that the consumer pays $p=\alpha$ for a unit of the product. The firm will then find it optimal to choose $\mathrm{x}=\overline{\mathrm{x}}^{\mathrm{SL}}$ and, having implemented this choice, it expects to make profits of $\alpha-\operatorname{FMC}\left(\overline{\mathrm{x}}^{\mathrm{SL}}\right)$. However, instead of simply taking delivery of the product, the consumer could now offer to waive liability in exchange for a revised price of $\mathrm{p}^{\mathrm{r}} \equiv \alpha-\mathrm{h}\left(\overline{\mathrm{x}}^{\mathrm{SL}}\right)-2 \mathrm{k}\left(\overline{\mathrm{x}}^{\mathrm{SL}}\right)+\varepsilon$ (where again $\varepsilon$ is a small positive number). Since the care level $\overline{\mathrm{x}}^{\mathrm{SL}}$ is already embodied in the product, if the firm accepts this offer then it will make $\varepsilon$ more in profit, so it is willing to accept. The consumer would be willing to pay $\alpha-\mathrm{h}\left(\overline{\mathrm{x}}^{\mathrm{SL}}\right)$ for a unit with no liability, so her proposal to waive liability in exchange for the revised price $\mathrm{p}^{\mathrm{r}}$ allows her to capture all but $\varepsilon$ of the expected litigation $\operatorname{costs} 2 \mathrm{k}\left(\overline{\mathrm{x}}^{\mathrm{SL}}\right)$, which are saved under no liability. Thus, the consumer will want to make this offer. But if, following the conclusion of the original contract over liability but prior to the implementation of the care decision, the firm anticipates that the consumer will re-open negotiations and offer to waive liability if the firm will

\footnotetext{
${ }^{26}$ This observation was made by Arlen and MacLeod (2003) in the context of medical malpractice; a formal model incorporating renegotiation in the context of products liability is provided in Wickelgren (2005).
} 
accept the price $\mathrm{p}^{\mathrm{r}}$, then the firm will choose care $\mathrm{x}$ to maximize $\mathrm{p}^{\mathrm{r}}-\mathrm{c}(\mathrm{x})$, leading to $\mathrm{x}=\mathrm{x}_{\min }$. The firm's incentive to provide care is completely undermined by the potential for renegotiation. ${ }^{27}$

Choi and Spier (2010) provide a model wherein, as above, the firm's level of care is unobservable to consumers prior to purchase, and wherein contractual liability could, in principle, solve the problem of under-provision of care. They abstract from the renegotiation issue described above (and from litigation costs, either under contractual or mandatory liability), but they show that another problem - adverse selection on the part of consumers - can still render contractual liability inefficient in terms of the level of care provided. They assume that there are two types of consumer, one of which is inherently less likely to be injured by the product. Competitive firms offer contracts specifying a price and stipulated damages in the event of an accident. In order for contractual liability to provide the right incentives for care, the stipulated damages must cover the full expected losses of the consumers. But if, due to perfect competition, firms just break even facing the full pool of consumers, then they would have an incentive to offer a contract involving a lower price and less-than-full compensation that is designed to appeal only to low-risk consumers. In a competitive equilibrium, firms offer a menu of contracts; the high-risk consumer is offered full insurance while the low-risk consumer is offered only partial insurance (see Rothschild and Stiglitz, 1976). ${ }^{28}$ The combined incentives for care are thus too low under contractual liability; incentives for efficient care are provided by mandating full (and unwaivable) liability.

\footnotetext{
${ }^{27}$ In Wickelgren (2005) the firm chooses to invest in care or not. In addition to the no-investment equilibrium that parallels our finding above, he finds a mixed-strategy equilibrium in which the firm invests with positive probability.

${ }^{28}$ Choi and Spier also consider parameter values such that the high-risk consumers should not (at a social optimum) consume the product. In the competitive equilibrium, they are screened out by a contract offer (involving partial insurance) that is attractive only to low-risk consumers, but such a contract does not induce efficient care. However, full mandated liability may not be preferable (e.g., when the fraction of high-risk consumers is sufficiently large).
} 
Second, in Section 3.2 we considered a model in which the firm privately learns the realized safety level of the product prior to sale, while the consumer does not. Under no liability (or even under strict liability with a sufficient amount of residual under-compensation), this resulted in an upward-distorted price that signaled higher product safety to the consumer. Although the consumer can infer the safety level, her consumption decision is inefficient due to the price distortion. Both the firm and the consumer are worse off under asymmetric information. On the other hand, under strict liability with little residual under-compensation, equilibrium involved a downward-distorted price that signaled higher product safety to the consumer; now the consumer is better off under asymmetric information, while the firm is still worse off (since it is still distorting its price away from the full-information price for signaling purposes). One might think that a firm could solve this problem by simply volunteering to absorb full liability for the consumer's harm. In this case (the argument goes), the consumer would no longer worry about the product's safety and thus no signaling distortion would arise. The firm would face the full marginal cost associated with its true product type (level of safety).

Spence (1977) argues that voluntary liability can serve as a signal of quality when a firm's type is unobservable to the consumer. ${ }^{29}$ Since firms choose both price and the level of liability in his model, this issue should be analyzed in the context of one dimension of private information and

\footnotetext{
${ }^{29}$ The terms "warranty" and "voluntary liability" (or "stipulated damages") are often used interchangeably. This is fine when warranty is modeled as a cash payment in the event the product fails as in Grossman (1981) and Lutz (1989). However, when warranty is modeled as a promise to physically replace a failed unit, then this equivalence breaks down. This is for (at least) two reasons: 1) it is less costly for a firm to replace a unit than for a consumer to do so, since the retail price may exceed marginal cost (see Brown, 1974, and Epple and Raviv, 1989); and 2) if the firm faces increasing marginal costs or capacity constraints (as in Schwartz and Wilde, 1983, 1985) then the promise to replace failed units results in higher marginal costs or a diversion of productive capacity from new sales to replacements. These models are not readily re-interpreted in the context of products liability.
} 
two potential signaling instruments. ${ }^{30}$ In such models it is typical for both instruments to be employed in equilibrium; that is, one would not necessarily expect to see a separating equilibrium in which all firm types promise a full warranty and then charge their full-information prices. The more general problem of signaling private information about safety with multiple instruments (e.g., price and voluntary liability) is quite challenging and in need of further research. ${ }^{31}$

However, when a firm offers to absorb liability, there is a problem of time inconsistency. When faced with a claim, the firm is likely to resist paying and the consumer will have to resort to court to enforce the contract; she will have to prove that the defendant's product caused her harm, and document its extent, and so on. Thus, "voluntary" liability is likely to degenerate into the same legal scenario as in strict liability and will likely involve some residual under-compensation. ${ }^{32}$ Consequently, consumers may also be skeptical of the firm's offer of contractual liability: now the consumer is acquiring two products of unknown quality from the firm. It does not appear that contractual liability has any substantial advantage (in this particular model) over mandatory liability.

Third, reconsider the model of Section 4, wherein the level of care was observable but

\footnotetext{
${ }^{30}$ Spence's model involves unit demand and competitive firms, and firms choose both price and the payment to the consumer should the product fail. He argues that price alone cannot serve as a signal of quality in a competitive market and goes on to analyze voluntary liability as the sole signaling instrument. However, if firms have some market power and consumers can purchase probabilistically, then price alone can signal quality; see Daughety and Reinganum (1997, 2005) and Ellingsen (1997) for monopoly models and Janssen and Roy (2010) for an oligopoly model.

31 The one paper in this area of which we are aware is Lutz (1989), which employs two firm types and also involves unobservable effort on the part of the consumer. Geistfeld (1988) argues that the extent of warranty coverage could serve as a signal of product safety, but only if the product and the warranty are priced separately. One price for the combined product plus the associated insurance confounds two aspects of information about which the consumer is arguably uninformed: production costs and the manufacturer's estimate of expected harm. A formal model of this situation would entail two aspects of private information and two potential signaling instruments; this is an interesting open question.

${ }^{32}$ One might argue that the firm could offer a highly-inflated voluntary liability payment so that the consumer would be made whole in expectation even if the firm subsequently tried to avoid paying off under the warranty. Very high stipulated damages can run afoul of the penalty doctrine, under which the common law does not enforce stipulated damages in excess of expected damages (Rea,1998, p. 24).
} 
generated an endogenous fixed cost. While no general result emerged from that analysis regarding whether strict liability or no liability provided higher welfare (the result would vary from market to market), let us consider a hypothetical market wherein strict liability would result in safer products and higher welfare than no liability. We will then ask whether contractual liability, implemented on an individual basis, is likely to result in the strict liability regime being implemented and the socially-efficient level of care being chosen.

Assume that the care level $\mathrm{x}$ is viewed as a long-run decision that is made early in the cycle of product design, production and, eventually, sale. ${ }^{33}$ As such, it does not vary with the liability status chosen by the consumer, and hence $\mathrm{h}(\mathrm{x})$ and $\mathrm{c}(\mathrm{x})$ are the same for all consumers. However, the price of the good, and thus the quantity purchased, will differ depending on the liability status selected by the consumer. This is because the price must reflect the full marginal cost and $\mathrm{FMC}^{\mathrm{NL}}(\mathrm{x})$ $<\mathrm{FMC}^{\mathrm{SL}}(\mathrm{x})$ because the latter includes expected litigation costs $2 \mathrm{k}(\mathrm{x})$. Thus, a consumer who purchases with no liability will pay a lower price and buy a larger amount than one who purchases with strict liability; since this consumer will enjoy the same level of care, she will also obtain a higher level of utility than a consumer who chooses strict liability. Since our consumers are riskneutral, they do not have an insurance motive, and hence it is a dominant strategy to purchase at the lower (no-liability) price. The firm, anticipating that consumers will choose no-liability contracts, will choose $\mathrm{x}$ to minimize $\mathrm{FMC}^{\mathrm{NL}}(\mathrm{x})$. Since, by hypothesis, strict liability would have resulted in safer products and higher welfare than no liability, we find that contractual liability does not result

\footnotetext{
33 As mentioned in Section 3, Daughety and Reinganum (1995) also models investment in safety as a long-run decision taken in advance of any production. Arlen and MacLeod (2003) and Arlen (2010) make a similar argument in the context of medical malpractice. Since a physician must make a lump-sum investment in expertise early in his career, the extent of this investment will be determined by the anticipated lifetime stream of patients and associated liability risks; no single patient's choices (about liability status) will influence the physician's early investment in expertise.
} 
in the strict liability regime being implemented and the socially-efficient level of care being chosen.

Finally, Landes and Posner (1985) argue that voluntary contracting is likely to have very high transactions costs (they envision consumers having to become well-informed about lowprobability events and the cost of the associated harms, and having to incorporate these into contracts) whereas making firms liable is conjectured to entail lower information costs (some of the relevant information may be available at low cost through the design and production of, and greater familiarity with, the product). As they put it (p. 545): "High information costs relative to the benefits of the information may defeat voluntary contracting."

\section{Conclusions}

While the idealized model in Section 2 provided a clean, unified discussion of products liability, more recent work has shown that the departures from the assumptions listed in Section 2 suggest that the ideal model has significant limitations when it comes to thinking about policy. As seen in Section 3, the possibility of systematic differences in information between consumers and firms leads to market failures, whether those differences arise prior to sale or after sale. As discussed in Section 4, if investment in care generates fixed costs (independent of the level of output) then the separability between efficient care decisions and market structure does not occur: to evaluate whether a firm has provided due care now relies upon understanding the degree of competitiveness of the market. Finally, as discussed in Section 5, while some scholars have urged substituting contractual liability for mandatory liability, recent analysis of this problem has again shown that individually-negotiated contractual liability is hampered by problems of asymmetric information, free riding, time inconsistency, inefficient market exchange, and costly enforcement. 


\section{References}

Akerlof, George. 1970. "The Market for "Lemons:” Quality Uncertainty and the Market Mechanism," 84 Quarterly Journal of Economics 488-500.

Arlen, Jennifer. 2010. "Contracting Over Liability: Medical Malpractice and the Cost of Choice," 158 University of Pennsylvania Law Review 957-1023.

Arlen, Jennifer, and W. Bentley MacLeod. 2003. "Malpractice Liability for Physicians and Managed Care Organizations," 78 New York University Law Review 1929-2006.

Ben-Shahar, Omri. 1998. "Should Products Liability be Based on Hindsight?” 14 Journal of Law, Economics, and Organization 325-357.

Brown, John P. 1974. "The Case of an Asset with Random Life," 64 American Economic Review 149-161.

Choi, Albert and Kathryn Spier. 2010. "Should Consumers be Permitted to Waive Products Liability? Product Safety, Private Contracts, and Adverse Selection," Harvard Law School Discussion Paper No. 680.

Congressional Budget Office. 2006. "Research and Development in the Pharmaceutical Industry."

Craswell, Richard, and John E. Calfee. 1986. "Deterrence and Uncertain Legal Standards," 2 Journal of Law, Economics, \& Organization 279-303.

Daughety, Andrew F., and Jennifer F. Reinganum. 1995. "Product Safety: Liability, R\&D and Signaling," 85 American Economic Review 1187-1206.

Daughety, Andrew F., and Jennifer F. Reinganum. 1997. "Everybody Out of the Pool: Products Liability, Punitive Damages and Competition," 13 Journal of Law, Economics and Organization 410-432.

Daughety, Andrew F., and Jennifer F. Reinganum. 2005. "Secrecy and Safety," 95 American Economic Review 1074-1091.

Daughety, Andrew F., and Jennifer F. Reinganum. 2006. "Markets, Torts and Social Inefficiency," 37 RAND Journal of Economics 300-323.

Daughety, Andrew F., and Jennifer F. Reinganum. 2008a. "Communicating Quality: A Unified Model of Disclosure and Signaling," 39 RAND Journal of Economics 973-989.

Daughety, Andrew F., and Jennifer F. Reinganum. 2008b. "Products Liability, Signaling and 
Disclosure," 164 Journal of Institutional and Theoretical Economics 106-126.

Ellingsen, Tore. 1997. "Price Signals Quality: The Case of Perfectly Inelastic Demand," 16 International Journal of Industrial Organization 43-61.

Epple, Dennis and Artur Raviv. 1978. "Product Safety: Liability Rules, Market Structure, and Imperfect Information, 68 American Economic Review 80-95.

Epstein, Richard A. 1985. "Products Liability as an Insurance Market," 14 Journal of Legal Studies 645-669.

Geistfeld, Mark. 1988. "Imperfect Information, the Pricing Mechanism, and Products Liability," 88 Columbia Law Review 1057-1072.

Geistfeld, Mark. 1994. "The Political Economy of Neocontractual Proposals for Products Liability Reform," 72 Texas Law Review 803-847.

Goldberg, John C.P., and Benjamin C. Zipursky. 2010. "The Easy Case for Products Liability Law: A Response to Professors Polinsky and Shavell," 123 Harvard Law Review, 1919-1948.

Grossman, Sanford. 1981. "The Informational Role of Warranties and Private Disclosure about Product Quality," 24 Journal of Law and Economics 461-483.

Hay, Bruce, and Kathryn E. Spier. 2005. "Manufacturer Liability for Harms Caused by Consumers," 95 American Economic Review 1700-1711.

Hua, Xinyu. 2011. "Product Recall and Liability," 27 Journal of Law, Economics, and Organization 113-136.

Janssen, Maarten, and Santanu Roy. 2010. "Signaling Quality Through Prices in an Oligopoly, 68 Games and Economic Behavior 192-207.

Jovanovic, Boyan. 1982. "Truthful Disclosure of Information," 13 Bell Journal of Economics 3644.

Landes, William M. and Richard A. Posner. 1981. "The Positive Theory of Tort Law," 15 Georgia Law Review, 851-924.

Landes, William M. and Richard A. Posner. 1985. "A Positive Economic Analysis of Products Liability," 14 Journal of Legal Studies 535-567.

Lutz, Nancy A. 1989. "Warranties as Signals under Consumer Moral Hazard,” 20 RAND Journal of Economics 239-255. 
Marino, Anthony M. 1997. "A Model of Product Recalls with Asymmetric Information," 12 Journal of Regulatory Economics 245-265.

Matthews, Steven A. and Andrew Postlewaite. 1985. "Quality Testing and Disclosure," 16 RAND Journal of Economics 328-340.

Milgrom, Paul. 1981. "Good News and Bad News: Representation Theorems and Applications," 12 Bell Journal of Economics 380-391.

Polinsky, A. Mitchell. 1980. "Strict Liability vs. Negligence in a Market Setting," 70 American Economic Review 363-367.

Polinsky, A. Mitchell and William P. Rogerson. 1983. "Products Liability, Consumer Misperceptions, and Market Power,"14 Bell Journal of Economics 581-589.

Polinsky, A. Mitchell, and Steven Shavell. 2010. “The Uneasy Case for Product Liability," 123 Harvard Law Review 1437-1493.

Polinsky, A. Mitchell and Steven Shavell. Forthcoming. "Mandatory versus Voluntary Disclosure of Product Risks," Journal of Law, Economics, and Organization.

Rea, Samuel A., Jr. 1998. "Penalty Doctrine in Contract Law," in Peter Newman, Ed., New York: Stockton Press, 3 The New Palgrave Dictionary of Economics and the Law 23-37.

Rothschild, Michael and Joseph E. Stiglitz. 1976. "Equilibrium in Competitive Insurance Markets: an Essay in the Economics of Imperfect Information," 80 Quarterly Journal of Economics 629-649.

Shavell, Steven. 1980. "Strict Liability versus Negligence," 9 Journal of Legal Studies 1-25.

Shavell, Steven. 1994. "Acquisition and Disclosure of Information Prior to Sale," 25 RAND Journal of Economics 20-36.

Schwartz, Alan and Louis L. Wilde. 1983. "Imperfect Information in Markets for Contract Terms: The Examples of Warranties and Security Interests," 69 Virginia Law Review 1387-1485.

Schwartz, Alan and Louis L. Wilde. 1985. "Quality and Imperfect Information," 52 Review of Economic Studies, 251-262.

Schwartz, Alan. 1988. Proposals for Products Liability Reform: A Theoretical Synthesis," 97 Yale Law Journal 353-419.

Spence, A. Michael Spence. 1975. "Monopoly, Quality, and Regulation," 6 The Bell Journal of Economics 417-429. 
Spence, Michael. 1977. "Consumer Misperceptions, Product Failure and Producer Liability," 44 Review of Economic Studies 561-572.

Spier, Kathryn E. Forthcoming. "Product Safety, Buybacks, and the Post-Sale Duty to Warn," Journal of Law, Economics, and Organization.

Spulber, Daniel F. 1989. Regulation and Markets. Cambridge: MIT Press

Viscusi, W. Kip. 1978. “A Note on 'Lemons' Markets with Quality Certification,” 9 Bell Journal of Economics 277-279.

Welling, Linda. 1991. "A Theory of Voluntary Recalls and Product Liability," 57 Southern Economic Journal 1092-1111.

Wickelgren, Abraham L. 2005. “The Inefficiency of Contractually-Based Liability with Rational Consumers," 22 Journal of Law, Economics, and Organization 168-183. 


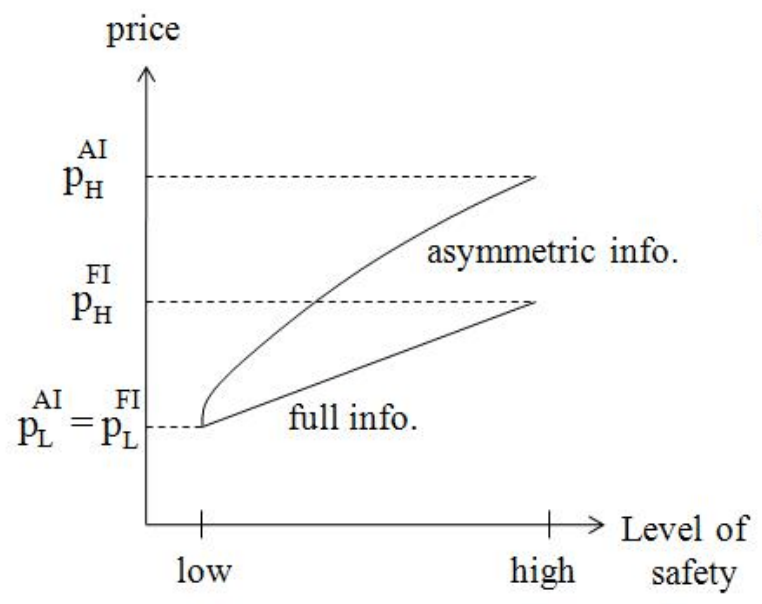

No liability for harm

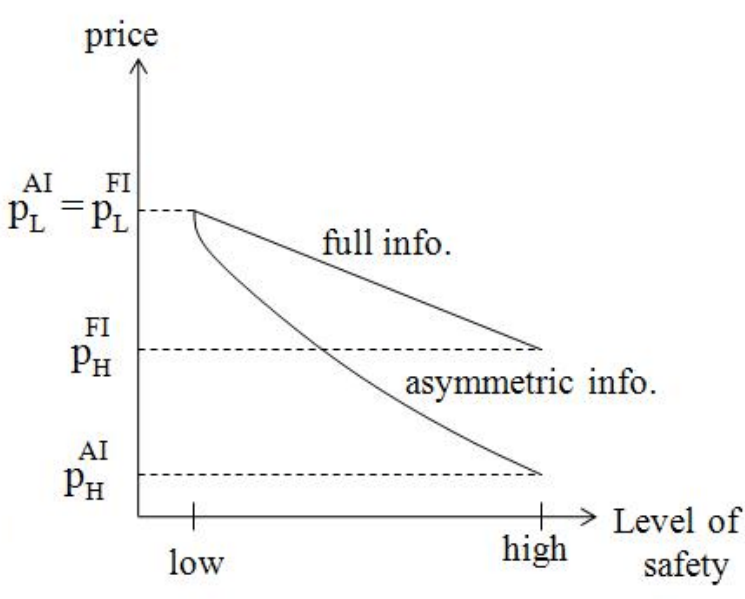

Strict liability for harm

Figure 1: The effect on pricing of allocating liability to the firm 


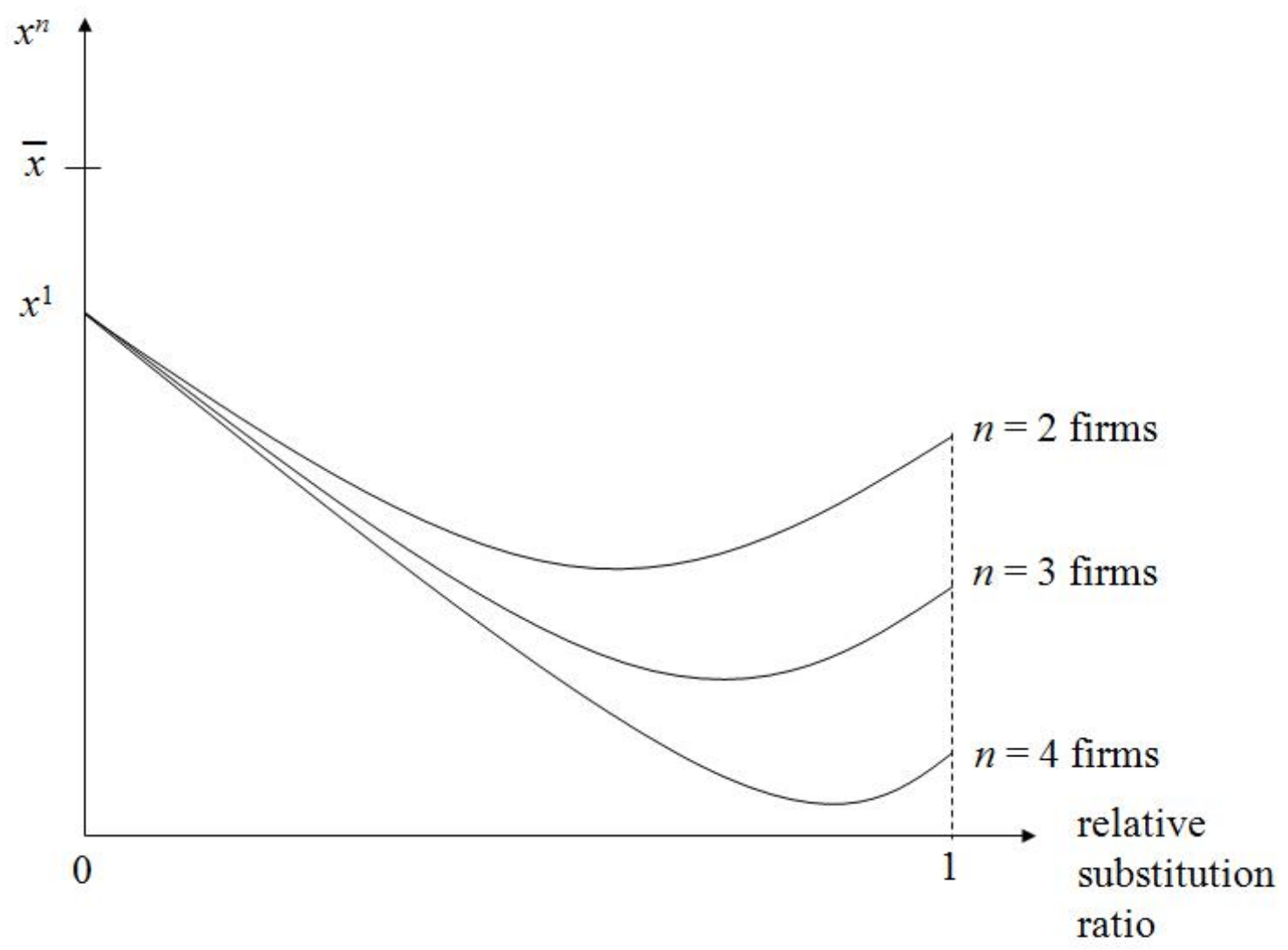

Figure 2: Equilibrium care as a function of the number of firms and the relative substitution ratio 


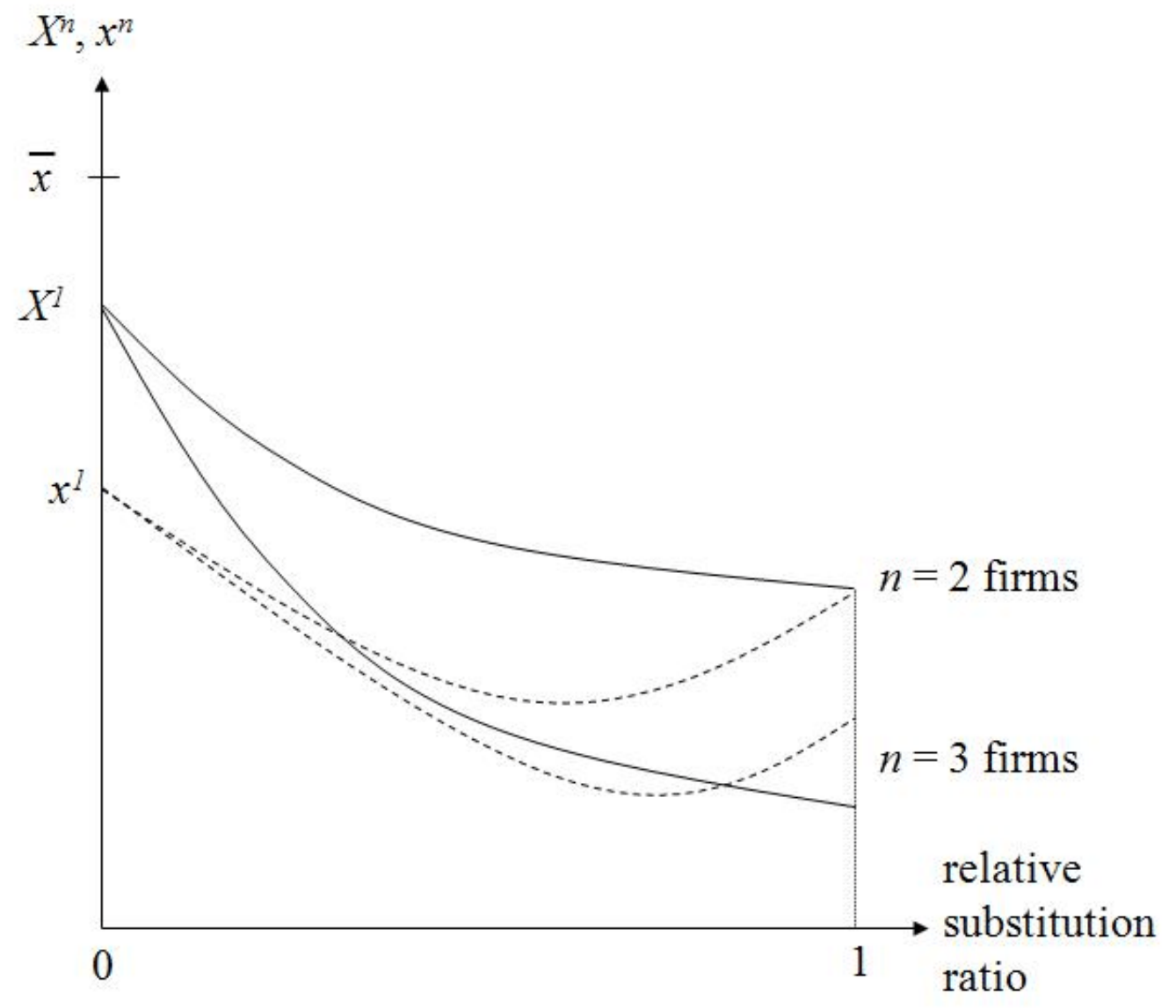

Figure 3: Comparison of socially-efficient and equilibrium care levels 